\title{
ON SERUM PROTEIN COMPONENTS AND LEUCOCYTE PERCENTAGE OF ERYTHEMA NODOSUM LEPROSUM
}

\author{
Michiyuki Kono and Hisaya Tsugami \\ Department of Dermatology, Osaka University Medical School \\ Hosaku Sakurai \\ National Leprosanatorim, Nagashima Aisei-En
}

\begin{abstract}
Results of analysis of serum protein with Tiselius' electrophoresis and the percentage of leucocytes at erythema nodosum leprosum were as following:

1) At the fading stadium from the acme or erythema, decrease of $\gamma$-globulin and increase of alubumin and $\alpha$-globulin were recognized.

2) $\beta$-globulin level was nigner than at lepra tuberosa and did not go down at this stadium.
\end{abstract}

3) Leucocytes increased in number at vanishing or erythema than at the peak. Neutrophile and eosinophile cells showed no change.

4 ) No corelation was found between serum protein fraction and percentage of leucocytes.

\section{瀨性結節性紅斑の血清蛋白組成 站に白血球百分比に就いて}

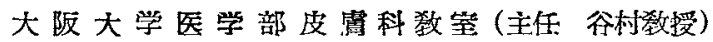
大阪大学微生物病砸所攋沿潦所研究部 (主任 谷村㸚授)
\end{abstract}

河野通之

津上大俩

国立療著所長島愛生園（主任 光田園長）

櫻 井方 策

\section{1 緒言}

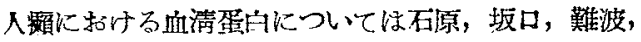
藤原の諸氏によつて研究報告せられている。そえによる

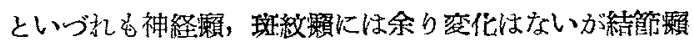

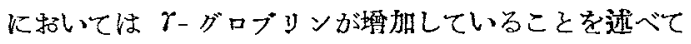

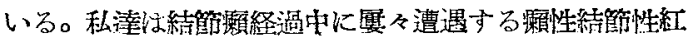
斑時に血清蛋白は如何なる㚆伦を示すか，なた白血球百 分此伦如何にあら注れて来るかを調べたのて，先人の行 つた成續と比较検討をして見たい。

\section{2 研究材料}

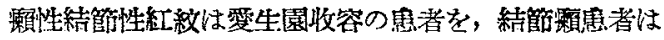
阪大涌院患者厄，これ等の人々は結核，梅毒等の合併淀 のないるのを撰択した。

\section{3 研究 方 法}

血清蛋白量湖定には日立の届折蛋白計を用い，血清蛋 白分算は日立製作所の H T - A 型 Tiselius 電合泳動裝 置を使用し，唀折ならびに添動条件は電気胀動研究会規 定に従つて行い，面積測定は上我脚をとり重量法により 測定した。

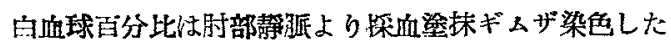


あのを検鏡した。

\section{4 成 績}

\section{I）血清蛋白組成について}

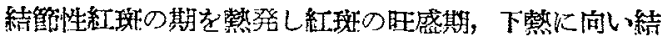

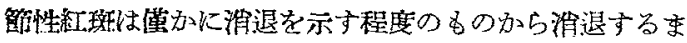
でを吸收期とし，結䈟性紅猛の吸收されて㱠ど認められ なくなつた湓退期の 3 期に分けた。

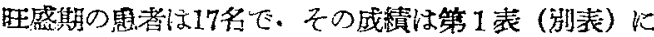

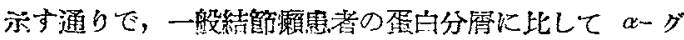

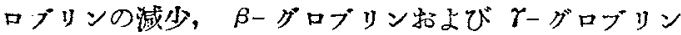
の墂加が見られる。

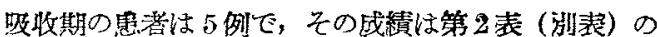
通りである。即ち旺盛期に比しアルブミンは精好歠加を 示し， $\beta$-グロブリン，および 示している。

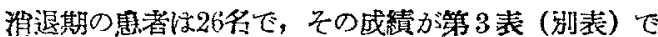
岕る。

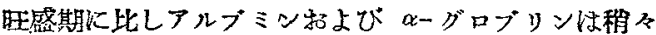
堬加を示し，ßーグロブリン括よび $7 ， 15 ， 17 ， 25 ， の 4$ 例以外は総て減少を示している。

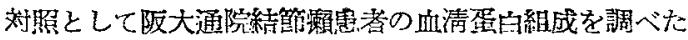
成靕が第4表（別表）でる。

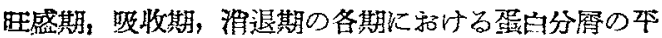
均を1表に穼とめると第 5 表（別表）のよ5になる。

第5表で目につくのは が吸收期，消退期と潮次減少して旧㙏していく上5で

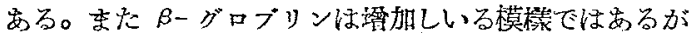
消退期に入つても旧に復さ政ことで出る。

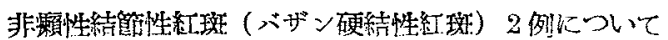

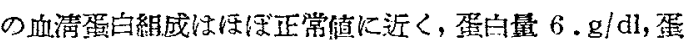

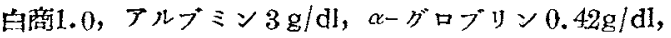

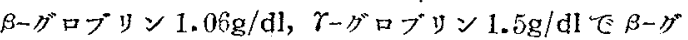
ロブリンの墂加が認められる。

\section{II) 白血球百分比について}

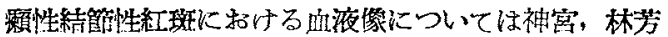

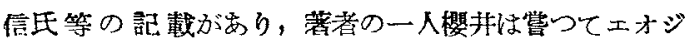

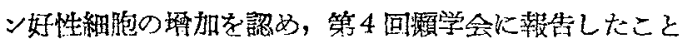

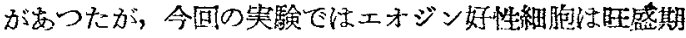

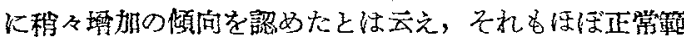

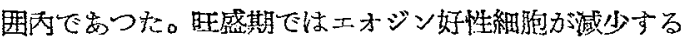
と云5通念炕なつているが，旺盛期と云つても，その状 態，その特に上つては多少の変化は步るすのだある。我
々の成績のエオジン好性細胞のほ悟正常值と云万のは， 種々の状熊の旺盛期をひきくるめて品る。泮巴球注消退 期に返つて虂加を示している点は林氏の派告に一政す る。

此处に林，神営、棚瀨，谷奥氏等の成績と比較してみ ると第6 表 (別表)のようになる。

林民は中好性細胞の㢦加を速べているが，私共の成綪 では殆ど墂加は㑇められなかかた。

\section{5 總括並に考按}

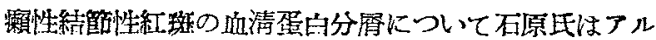

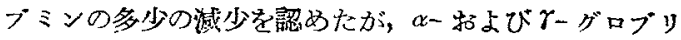

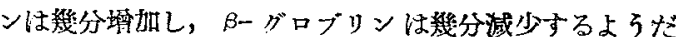
々述へている。李大蜼波，藤原氏等はフルブミンの減少

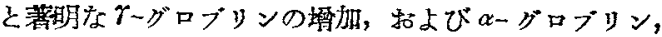
ßーグロブリンの謤加を连へている。

私共の成績でアルブミンの多少の減少を唃め，てーグ

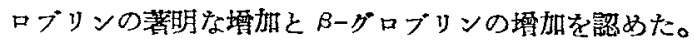
雨来紅斑の樶收们向うにつれて

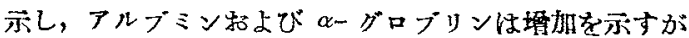

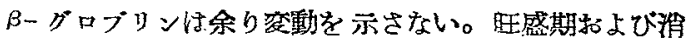
退期の経瀜を道つて調へ得大症例が14例㟧るので，その

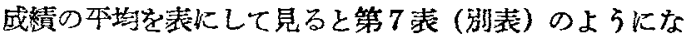
る。

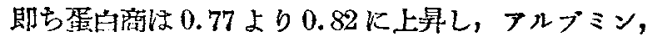

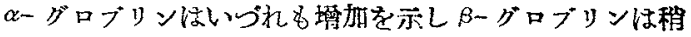
々淢少の攧向に㚣る程度で変化なく，ケーグロブリンは

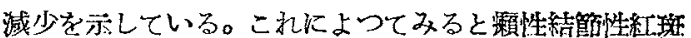

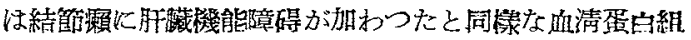

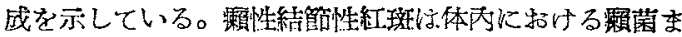

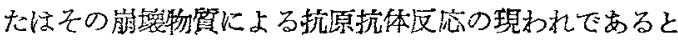

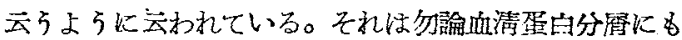
殿伦を来すべく，我々の成績では大部分のすのに ロブリンが墂加し，旺盛期より吸收，消退えと移行につ れての減少山発生前の犆にまで復していくと見たい。そ して4例の例外性果して偶然の例外であつたが゙うか， 組織病湾と共に今後究明すべき点で㔖るが，或は血清親 和性抗体，組織親和性抗体の二核の反究形式があつてそ れによる相逞ではなからうか。白血球百分比を見ると工

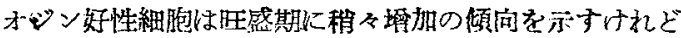

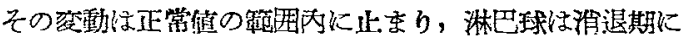
向つてか方つて墂加を示している。

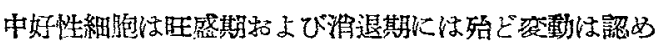
られない。血清蛋白分廏と白血球百分此の間には相関関 
保は認められなかつた。

\section{6 結 論}

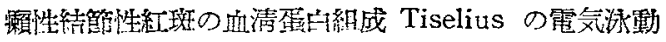
洗により分析すると共に白血球百分比をも研せ調べた。

1） ケーグロブリンは旺盛期より消退期に向い隇少を 示した。

2）アルブミン， に向い樰加を示している。

3） $\beta$-グロブリンは結籍観の维より高くかつ消退期 に向つても余り変動を示さない。

4）漱巴球は旺盛期より消退期に墂加を示し，中好性 細胞は殆ど変動を認めない。

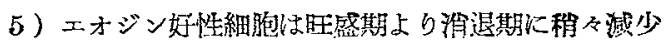
を示すがいつれも正常範囲內で娄つた。

6）血清蛋白分㞕と白血球百分比々の間には特放の相 関䦛保は認められなかつた。

\section{主 要 交 献}

1) 平井 日新医学 35 鉒 3 号 1948

2) 本井 日新医学 35 卷 4 号 1948

3) 有山 血液学詩議会 第一輯 1948

4) Erich: W.F and Harris, T.N. J. Exp. Med. $73: 385,1942$

5) Dougherty : T.E, Chase, J.H. and White A :

Pros. soc. Exp. Biol $57: 295,1944$

6) 石原 レプラ 19器 5 号 1950

7) 不原 レプラ 19 卷 6 号 1951

8) 故口 レプラ 20 先 2 号 1951 .

9）難波, 藤原 レプラ 2l参 1 号 1.952

10）神蒠 レプラ 1 㪇 4 号 $19: 0$

11）櫻井 レプラ 2 然 2 号 1981

12）棚瀨 皮雷科紀要 10卷 4号 1980

13）林芳信 東京医誌 27.42 号 1931

14）阿部 レプラ 5 聕 1 号 1934

15）阿部 レプラ 7 兊 1 号 193

16)立川 レプラ 7 参 1 号 $19 x$

17）武田 レプラ 7 尜 1 号 1936

18）阿部 レプラ 10 卷 2 号 19 路

(この研究の一部は科学研究費によつた。谷村）
第 1 表 旺盛期に於勀る血清蛋白組成

\begin{tabular}{|c|c|c|c|c|c|c|c|c|}
\hline \multirow{2}{*}{$\begin{array}{l}\text { 窝 } \\
\text { 烈 } \\
\text { 番 } \\
\text { 号 }\end{array}$} & \multirow{2}{*}{$\begin{array}{l}\text { 性 } \\
\text { 施 }\end{array}$} & \multirow{2}{*}{$\begin{array}{l}\text { 年 } \\
\text { 令 }\end{array}$} & \multirow{2}{*}{$\begin{array}{l}\text { 胥 } \\
\text { 肖 } \\
\text { 量 }\end{array}$} & \multirow[t]{2}{*}{$\mathrm{A} / \mathrm{G}$} & \multirow{2}{*}{$\mathrm{A} \frac{\mathrm{gf} / \mathrm{dl}}{\%}$} & \multicolumn{3}{|c|}{ グロブリン $\frac{\mathrm{gr} / \mathrm{d} l}{\%}$} \\
\hline & & & & & & $\alpha$ & $\beta$ & $\gamma$ \\
\hline 2 & $\delta$ & 35 & 7.6 & 0.49 & $\begin{array}{r}2.5 \\
32.8\end{array}$ & $\begin{array}{l}1.29 \\
17.1\end{array}$ & $\begin{array}{l}0.97 \\
12.8\end{array}$ & $\begin{array}{l}2.81 \\
37.1\end{array}$ \\
\hline 3 & $\delta$ & 30 & 7.2 & 0.64 & $\begin{array}{r}2.8 \\
39.1\end{array}$ & $\begin{array}{l}0.93 \\
18.0\end{array}$ & $\begin{array}{l}0.98 \\
1.3 .0\end{array}$ & $\begin{array}{l}2.49 \\
34.7\end{array}$ \\
\hline 4 & $\delta$ & 24. & 10.0 & 0.68 & $\begin{array}{r}4.0^{*} \\
40.6^{*}\end{array}$ & $\begin{array}{l}0.6 \\
6.7\end{array}$ & $\begin{array}{r}1.5 \\
15.2\end{array}$ & $\begin{array}{r}3.7 \\
37.2\end{array}$ \\
\hline 5 & $\hat{\delta}$ & 23 & 8.4 & 0.54 & $\begin{array}{l}2.95 \\
35.2\end{array}$ & $\begin{array}{r}0.77 \\
9.2\end{array}$ & $\begin{array}{l}1.54 \\
18.4\end{array}$ & $\begin{array}{l}3.09 \\
36.8\end{array}$ \\
\hline 7 & $\delta$ & 35 & 8.0 & 0.19 & $\begin{array}{l}4.34 \\
54.3\end{array}$ & $\begin{array}{r}0.68 \\
8.6\end{array}$ & $\begin{array}{l}0.86 \\
10.8\end{array}$ & $\begin{array}{l}2.08 \\
26.0\end{array}$ \\
\hline 10 & $\delta$ & 25 & 11.0 & 0.44 & $\begin{array}{l}3.46 \\
31.5\end{array}$ & $\begin{array}{r}0.85 \\
7.8\end{array}$ & $\begin{array}{l}1.72 \\
15.7\end{array}$ & $\begin{array}{l}4.63 \\
42.1\end{array}$ \\
\hline 11 & $\hat{o}$ & 29 & 6.0 & 0.88 & $\begin{array}{l}2.92 \\
\pm 8.8\end{array}$ & $\begin{array}{l}0.79 \\
13.3\end{array}$ & $\begin{array}{l}0.66 \\
11.1\end{array}$ & $\begin{array}{l}1.99 \\
33.3\end{array}$ \\
\hline 12 & $\hat{\delta}$ & 31 & 7.0 & $0.70^{\circ}$ & $\begin{array}{l}3.02 \\
48.2\end{array}$ & $\begin{array}{l}0.75 \\
10.8\end{array}$ & $\begin{array}{l}1.09 \\
15.6\end{array}$ & $\begin{array}{l}2.07 \\
29.7\end{array}$ \\
\hline 15 & $\hat{0}$ & 42 & 7.4 & 0.75 & $\begin{array}{l}3.16 \\
42.8\end{array}$ & $\begin{array}{r}0.4 .2 \\
5.7\end{array}$ & $\begin{array}{l}1.26 \\
17.1\end{array}$ & $\begin{array}{l}2.53 \\
34: 2\end{array}$ \\
\hline 17 & $\delta$ & 32 & 7.8 & 0.61 & $\begin{array}{l}3.13 \\
40.2\end{array}$ & $\begin{array}{l}1.16 \\
14.9\end{array}$ & $\begin{array}{l}1.23 \\
15.8\end{array}$ & $\begin{array}{l}2.26 \\
29.0\end{array}$ \\
\hline 18 & 우 & 25 & 6.6 & 0.90 & $\begin{array}{l}3.14 \\
17.6\end{array}$ & $\begin{array}{r}0.31 \\
4.7\end{array}$ & $\begin{array}{l}0.98 \\
14.2\end{array}$ & $\begin{array}{l}2.19 \\
33.3\end{array}$ \\
\hline 19 & $\hat{\delta}$ & 42 & 6.8 & 0.70 & $\begin{array}{r}2.8 \\
41.3\end{array}$ & $\begin{array}{l}0.73 \\
10.8\end{array}$ & $\begin{array}{l}0.88 \\
13.0\end{array}$ & $\begin{array}{l}2.35 \\
34.7\end{array}$ \\
\hline 21 & 우 & $5 \%$ & 6.8 & 0.62 & $\begin{array}{l}2.61 \\
38.4\end{array}$ & $\begin{array}{r}0.65 \\
9.0\end{array}$ & $\begin{array}{l}0.78 \\
11.5\end{array}$ & $\begin{array}{l}2.73 \\
40.2\end{array}$ \\
\hline 22 & $\delta$ & 40 & 67 & 0.69 & $\begin{array}{l}2.74 \\
40.9\end{array}$ & $\begin{array}{l}0.76 \\
11.4\end{array}$ & $\begin{array}{l}0.87 \\
13.1\end{array}$ & $\begin{array}{r}2.3 \\
34.4\end{array}$ \\
\hline 21 & $\hat{\sigma}$ & 1.5 & 7.2 & 0.81 & $\begin{array}{l}3.22 \\
4.4 .8\end{array}$ & $\begin{array}{l}0.98 \\
13.7\end{array}$ & $\begin{array}{l}0.98 \\
13.7\end{array}$ & $\begin{array}{l}1.98 \\
27.5\end{array}$ \\
\hline 25 & $\delta$ & 33 & (i. 8 & 0.71 & $\begin{array}{l}2.82 \\
41.6\end{array}$ & $\begin{array}{l}0.754 \\
11.1\end{array}$ & $\begin{array}{l}1,319 \\
19.4\end{array}$ & $\begin{array}{l}1.88 \\
27.7\end{array}$ \\
\hline 30 & $\delta$ & 35 & 7.0 & 0.88 & $\begin{array}{l}3.27 \\
46.8\end{array}$ & $\begin{array}{l}0.91 \\
13.0\end{array}$ & $\begin{array}{l}0.87 \\
12.5\end{array}$ & $\begin{array}{l}1.89 \\
27.0\end{array}$ \\
\hline 平 & & 均 & 7.0 & 0.72 & $\therefore 11$ & 0.78 & 1.08 & 2.52 \\
\hline
\end{tabular}


第2 表吸收期飞於ける車清蛋白組成

\begin{tabular}{|c|c|c|c|c|c|c|c|c|}
\hline \multirow{2}{*}{ 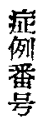 } & \multirow{2}{*}{$\begin{array}{l}\text { 性 } \\
\text { 別 }\end{array}$} & \multirow{2}{*}{$\begin{array}{l}\text { 年 } \\
\text { 令 }\end{array}$} & \multirow{2}{*}{$\begin{array}{l}\text { 蛋 } \\
\text { 白 } \\
\text { 量 }\end{array}$} & \multirow[t]{2}{*}{$\mathrm{A} / \mathrm{G}$} & \multirow{2}{*}{$\mathrm{A} \frac{\mathrm{gr} / \mathrm{dl}}{\%}$} & \multicolumn{3}{|c|}{ グロブリン $\frac{\mathrm{gr} / \mathrm{dl}}{\%}$} \\
\hline & & & & & & $\alpha$ & $\beta$ & $\gamma$ \\
\hline 8 & 8 & 52 & 7.2 & 0.57 & $\begin{array}{l}2.61 \\
36.3\end{array}$ & $\begin{array}{l}0.78 \\
10.9\end{array}$ & $\begin{array}{l}0.78 \\
10.9\end{array}$ & $\begin{array}{l}3.09 \\
41.8\end{array}$ \\
\hline 9 & $\hat{\delta}$ & 31 & 8.0 & 0.63 & $\begin{array}{l}3.08 \\
38.6\end{array}$ & $\begin{array}{l}0.88 \\
11.1\end{array}$ & $\begin{array}{l}0.88 \\
111\end{array}$ & $\begin{array}{l}3.08 \\
38.6\end{array}$ \\
\hline 13 & $\hat{s}$ & 39 & 6.0 & 0.88 & $\begin{array}{l}5.98 \\
47.0\end{array}$ & $\begin{array}{l}0.70 \\
11.7\end{array}$ & $\begin{array}{l}1.05 \\
17.6\end{array}$ & $\begin{array}{l}1.41 \\
23.5\end{array}$ \\
\hline 20 & $\hat{o}$ & 21 & 8.0 & 0.18 & $\begin{array}{l}3.23 \\
40.4\end{array}$ & $\begin{array}{l}0.76 \\
9.50\end{array}$ & $\begin{array}{l}1.13 \\
14.2\end{array}$ & $\begin{array}{l}2.85 \\
35.7\end{array}$ \\
\hline 29 & $\hat{\delta}$ & 35 & 7.0 & 1.20 & $\begin{array}{l}3.81 \\
54.5\end{array}$ & $\begin{array}{l}0.70 \\
10.1\end{array}$ & $\begin{array}{l}0.98 \\
14.1\end{array}$ & $\begin{array}{l}1.48 \\
21.2\end{array}$ \\
\hline 푸 & & 均 & 7.2 & 0.79 & 3.74 & 0.76 & 0.96 & 2.36 \\
\hline
\end{tabular}

第 3 表

消退期に於ける血清蚠白組成

\begin{tabular}{|c|c|c|c|c|c|c|c|c|c|c|c|c|c|c|c|c|c|}
\hline \multirow{2}{*}{$\begin{array}{l}\text { 症 } \\
\text { 列 } \\
\text { 番 }\end{array}$} & \multirow{2}{*}{$\begin{array}{l}\text { 性 } \\
\text { 尉 }\end{array}$} & \multirow{2}{*}{$\begin{array}{l}\text { 年 } \\
\text { 令 }\end{array}$} & \multirow{2}{*}{$\begin{array}{l}\text { 蛋 } \\
\text { 香 } \\
\text { 量 }\end{array}$} & \multirow{2}{*}{$\mathrm{A} / \mathrm{G}$} & \multirow{2}{*}{$\mathrm{A} \frac{\mathrm{gr} / \mathrm{dl}}{\%}$} & \multicolumn{3}{|c|}{ グロブリン $\frac{\mathrm{gr} / \mathrm{dl}}{\%}$} & \multirow{2}{*}{$\begin{array}{l}\text { 定 } \\
\text { 䆺 } \\
\text { 害 }\end{array}$} & \multirow{2}{*}{ 性 } & \multirow{2}{*}{$\begin{array}{l}\text { 年 } \\
\text { 命 }\end{array}$} & \multirow{2}{*}{$\begin{array}{l}\text { 蛋 } \\
\text { 白 } \\
\text { 量 }\end{array}$} & \multirow{2}{*}{$\mathrm{A} / \mathrm{G}$} & \multirow{2}{*}{$\mathrm{A} \frac{\mathrm{gr} / \mathrm{d} \mathrm{l}}{\%}$} & \multicolumn{3}{|c|}{ グロブリン $\frac{\mathrm{gr} / \mathrm{dl}}{\%}$} \\
\hline & & & & & & $\alpha$ & $\beta$ & $\gamma$ & & & & & & & $\alpha$ & $\beta$ & $\tau$ \\
\hline 1 & $\hat{o}$ & 26 & 7.8 & 0.58 & $\begin{array}{c}2.88 \\
37\end{array}$ & $\begin{array}{l}0.86 \\
11.1\end{array}$ & $\begin{array}{l}1.15 \\
14.8\end{array}$ & $\begin{array}{c}2.88 \\
37\end{array}$ & 16 & $\hat{a}$ & 25 & 7.0 & 0.66 & $\begin{array}{r}2.8 \\
40.0\end{array}$ & $\begin{array}{l}1.07 \\
15.4\end{array}$ & $\begin{array}{l}1.07 \\
15.4\end{array}$ & $\begin{array}{l}2.01 \\
28.8\end{array}$ \\
\hline 2 & $\hat{\delta}$ & 35 & 5.8 & 0.76 & $\begin{array}{l}2.5 \mathrm{I} \\
43.4\end{array}$ & $\begin{array}{r}0.55 \\
9.6\end{array}$ & $\begin{array}{l}0.75 \\
13.0\end{array}$ & $\begin{array}{l}2.01 \\
34.7\end{array}$ & 17 & $\delta$ & 32 & 9.0 & 0.70 & $\begin{array}{l}3.71 \\
41.3\end{array}$ & $\begin{array}{l}1.36 \\
15.2\end{array}$ & $\begin{array}{l}1.17 \\
13.0\end{array}$ & $\begin{array}{l}2.73 \\
30.4\end{array}$ \\
\hline 3 & $\hat{o}$ & 30 & 7.6 & 0.86 & $\begin{array}{l}3.52 \\
46.4\end{array}$ & $\begin{array}{l}0.81 \\
10.7\end{array}$ & $\begin{array}{l}1.07 \\
1.4 .2\end{array}$ & $\begin{array}{l}2.16 \\
28.5\end{array}$ & 18 & q & 25 & 8.0 & 1.00 & $\begin{array}{r}4.0 \\
50.0\end{array}$ & $\begin{array}{l}1.06 \\
13.3\end{array}$ & $\begin{array}{l}1.8 \\
16 .\end{array}$ & $\begin{array}{l}1.6 \\
20\end{array}$ \\
\hline 4 & $\hat{\sigma}$ & 24 & 7.0 & 0.80 & $\begin{array}{r}3.1 \\
44.4\end{array}$ & $\begin{array}{l}0.87 \\
12.5\end{array}$ & $\begin{array}{l}0.91 \\
13.0\end{array}$ & $\begin{array}{r}2.1 \\
30.0\end{array}$ & 19 & $\hat{o}$ & 42 & 7.4 & 0.85 & $\begin{array}{l}3.41 \\
46.1\end{array}$ & $\begin{array}{l}0.85 \\
11.5\end{array}$ & $\begin{array}{l}1.13 \\
15.3\end{array}$ & $\begin{array}{l}1.99 \\
26.9\end{array}$ \\
\hline 6 & $\hat{\alpha}$ & 32 & 7.2 & 0.71 & $\begin{array}{l}2.99 \\
41.6\end{array}$ & $\begin{array}{l}0.74 \\
10.4\end{array}$ & $\begin{array}{r}0.9 \\
12.5\end{array}$ & $\begin{array}{l}2.54 \\
35.4\end{array}$ & 20 & $\hat{\delta}$ & 21 & 8.0 & 0.67 & $\begin{array}{l}3.23 \\
40.4\end{array}$ & $\begin{array}{l}1.18 \\
14.8\end{array}$ & $\begin{array}{l}1.36 \\
17.0\end{array}$ & $\begin{array}{l}.3 .20 \\
27.6\end{array}$ \\
\hline 7 & $\hat{\delta}$ & 35 & 8.0 & 1.00 & $\begin{array}{r}4.0 \\
50.0\end{array}$ & $\begin{array}{r}0.76 \\
9.6\end{array}$ & $\begin{array}{l}0.83 \\
10.4\end{array}$ & $\begin{array}{r}2.0 \\
25.0\end{array}$ & 22 & $\hat{o}$ & 40 & 6.4 & 0.57 & $\begin{array}{l}2.34 \\
36.6\end{array}$ & $\begin{array}{l}0.85 \\
13.3\end{array}$ & $\begin{array}{l}1.28 \\
20.0\end{array}$ & $\begin{array}{l}1.95 \\
30.0\end{array}$ \\
\hline 8 & $\hat{\jmath}$ & 52 & 7.6 & 0.66 & $\begin{array}{l}3.04 \\
40.0\end{array}$ & & $\begin{array}{l}1.01 \\
13.3\end{array}$ & $\begin{array}{l}2.53 \\
33.3\end{array}$ & 23 & $q$ & 48 & 7.6 & 0.63 & $\begin{array}{l}3.04 \\
40.0\end{array}$ & $\begin{array}{l}1.02 \\
13.5\end{array}$ & & $\begin{array}{l}2.31 \\
30.5\end{array}$ \\
\hline 9 & $\delta$ & 31 & 8.0 & 0.68 & $\begin{array}{l}3.25 \\
40.7\end{array}$ & $\begin{array}{r}0.59 \\
7.4\end{array}$ & $\begin{array}{l}1.03 \\
12.9\end{array}$ & $\begin{array}{l}3.10 \\
38.8\end{array}$ & 24 & $\hat{\sigma}$ & 15 & 7.0 & 0.90 & $\begin{array}{l}3.31 \\
47.3\end{array}$ & $\begin{array}{l}0.98 \\
14.0\end{array}$ & & $\begin{array}{l}1.89 \\
27.0\end{array}$ \\
\hline 10 & $\hat{\delta}$ & 25 & 7.6 & 0.66 & $\begin{array}{l}3.36 \\
40.0\end{array}$ & $\begin{array}{r}0.71 \\
8.5\end{array}$ & $\begin{array}{l}1.68 \\
20.0\end{array}$ & $\begin{array}{l}2.63 \\
31.4\end{array}$ & 25 & $\hat{\delta}$ & 33 & 7.2 & 0.85 & $\begin{array}{l}3.31 \\
46.0\end{array}$ & $\begin{array}{l}0.86 \\
12.0\end{array}$ & & $\begin{array}{l}1.94 \\
27.0\end{array}$ \\
\hline 11 & $\hat{\delta}$ & 29 & 6.4 & 1.20 & $\begin{array}{l}3.48 \\
54.5\end{array}$ & $\begin{array}{l}0.83 \\
13.1\end{array}$ & $\begin{array}{l}0.72 \\
11.3\end{array}$ & $\begin{array}{l}1.30 \\
20.4\end{array}$ & 26 & $\hat{o}$ & 23 & 6.4 & 0.61 & $\begin{array}{l}2.42 \\
37.9\end{array}$ & $\begin{array}{l}0.87 \\
13.7\end{array}$ & & $\begin{array}{l}1.95 \\
30.5\end{array}$ \\
\hline 12 & $\hat{o}$ & 31. & 8.0 & 0.76 & & $\begin{array}{r}0.8 \\
10.0\end{array}$ & $\begin{array}{r}0.8 \\
10.0\end{array}$ & $\begin{array}{l}2.92 \\
36.6\end{array}$ & 27 & $\hat{o}$ & 28 & 7.2 & 0.68 & $\begin{array}{l}2.91 \\
40.5\end{array}$ & $\begin{array}{l}1.16 \\
16.2\end{array}$ & & $\begin{array}{l}2.13 \\
29.7\end{array}$ \\
\hline 13 & $\hat{s}$ & 39 & 8.0 & 0.66 & $\begin{array}{r}3.2 \\
40.0\end{array}$ & $\begin{array}{l}1.2 \\
8.5\end{array}$ & $\begin{array}{l}1.2 \\
20\end{array}$ & $\begin{array}{r}2.4 . \\
31.4\end{array}$ & 28 & $\delta$ & 30 & 7.4 & 0.75 & $\begin{array}{l}3.16 \\
42.8\end{array}$ & $\begin{array}{r}0.70 \\
9.5\end{array}$ & $\begin{array}{l}1.05 \\
14.2\end{array}$ & $\begin{array}{l}2.46 \\
33.3\end{array}$ \\
\hline 14 & $q$ & 39 & 7.8 & 1.00 & $\begin{array}{r}3.9 \\
50.0\end{array}$ & $\begin{array}{l}0.91 \\
11.7\end{array}$ & $\begin{array}{l}0.91 \\
11.7\end{array}$ & $\begin{array}{l}2.05 \\
26.4\end{array}$ & 平 & & 均 & & 0.76 & 3.21 & 0.89 & 1.06 & 2.28 \\
\hline 15 & t & 42 & 8.0 & 0.65 & $\begin{array}{l}3.16 \\
39.6\end{array}$ & $\begin{array}{l}0.96 \\
12.1\end{array}$ & $\begin{array}{r}1.2 \\
15.1\end{array}$ & $\begin{array}{l}2.66 \\
33.3\end{array}$ & & & & & & & & & \\
\hline
\end{tabular}


第 4 表 結節贋の血清蛋白組成

\begin{tabular}{|c|c|c|c|c|c|c|c|c|}
\hline \multirow{2}{*}{$\begin{array}{l}\text { 症 } \\
\text { 䎹 } \\
\text { 营 }\end{array}$} & \multirow{2}{*}{$\begin{array}{l}\text { 性 } \\
\text { 放 }\end{array}$} & \multirow{2}{*}{$\begin{array}{l}\text { 年 } \\
\text { 令 }\end{array}$} & \multirow{2}{*}{$\begin{array}{l}\text { 蛋 } \\
\text { 白 } \\
\text { 量 }\end{array}$} & \multirow{2}{*}{$A / G$} & \multirow{2}{*}{$\mathrm{A} \frac{\mathrm{gr} / \mathrm{dI}}{\%}$} & \multicolumn{3}{|c|}{ グロブリン $\frac{\mathrm{gr} / \mathrm{dl}}{\%}$} \\
\hline & & & & & & $\alpha$ & $\beta$ & $\gamma$ \\
\hline 31 & $\delta$ & 29 & 6.4 & 0.80 & $\begin{array}{l}2.97 \\
46.5\end{array}$ & $\begin{array}{r}0.39 \\
6.1\end{array}$ & $\begin{array}{r}0.49 \\
7.7\end{array}$ & $\begin{array}{r}2.5 \\
39.9\end{array}$ \\
\hline 32 & $\hat{z}$ & 30 & 6.4 & 0.87 & $\begin{array}{l}3.00 \\
47.0\end{array}$ & $\begin{array}{r}0.42 \\
6.7\end{array}$ & $\begin{array}{l}0.86 \\
13.5\end{array}$ & $\begin{array}{l}2.15 \\
33.7\end{array}$ \\
\hline 33 & 웅 & 37 & 6.6 & 0.80 & $\begin{array}{l}2.90 \\
44.8\end{array}$ & $\begin{array}{r}0.52 \\
8.0\end{array}$ & $\begin{array}{l}0.85 \\
13.0\end{array}$ & $\begin{array}{l}2.27 \\
3.44\end{array}$ \\
\hline 34 & 古 & 36 & 5.6 & 0.65 & $\begin{array}{l}2.21 \\
39.5\end{array}$ & $\begin{array}{r}0.53 \\
9.5\end{array}$ & $\begin{array}{l}1.09 \\
19.5\end{array}$ & $\begin{array}{l}1.76 \\
31.5\end{array}$ \\
\hline 35 & $\hat{o}$ & 44 & 5.4 & 0.78 & $\begin{array}{l}2.37 \\
44.0\end{array}$ & $\begin{array}{r}0.43 \\
8.0\end{array}$ & $\begin{array}{l}0.85 \\
15.8\end{array}$ & $\begin{array}{l}1.73 \\
32.2\end{array}$ \\
\hline 36 & $\hat{\sigma}$ & 42 & 8.6 & 0.91 & $\begin{array}{l}4.10 \\
47.7\end{array}$ & $\begin{array}{l}1.08 \\
12.0\end{array}$ & $\begin{array}{r}0.84 \\
9.8\end{array}$ & $\begin{array}{l}2.62 \\
30.5\end{array}$ \\
\hline 37 & $\hat{o}$ & 41 & 7.9 & 1.21 & $\begin{array}{l}4.33 \\
54.9\end{array}$ & $\begin{array}{r}0.53 \\
6.7\end{array}$ & $\begin{array}{l}0.88 \\
11.2\end{array}$ & $\begin{array}{l}1.87 \\
23.7\end{array}$ \\
\hline 38 & $\delta$ & 21 & 7.1 & 0.88 & $\begin{array}{l}3.34 \\
47.1\end{array}$ & $\begin{array}{r}0.51 \\
7.3\end{array}$ & $\begin{array}{l}0.92 \\
13.0\end{array}$ & $\begin{array}{l}2.31 \\
32.6\end{array}$ \\
\hline 39 & $\hat{\delta}$ & 35 & 7.0 & 0.90 & $\begin{array}{c}3.29 \\
47\end{array}$ & $\begin{array}{l}1.02 \\
14.7\end{array}$ & $\begin{array}{l}1.16 \\
16.7\end{array}$ & $\begin{array}{l}1.48 \\
24.2\end{array}$ \\
\hline 平 & & 均 & 6.7 & 0.86 & 3.16 & 0.59 & 0.88 & 2.07 \\
\hline
\end{tabular}

第 5 表 㾋性結節紅斑各期飞於りる 平均血清蛋白組成

\begin{tabular}{|c|c|c|c|c|c|c|}
\hline \multirow{2}{*}{ 区 分 } & \multirow{2}{*}{$\begin{array}{l}\text { 蛋 } \\
\text { 帒 } \\
\text { 量 }\end{array}$} & \multirow{2}{*}{$\mathrm{A} / \mathrm{G}$} & \multirow{2}{*}{ A } & \multicolumn{3}{|c|}{ グロブリン } \\
\hline & & & & $\alpha$ & $\beta$ & $\gamma$ \\
\hline 縕節攋 & 6.7 & 0.86 & 3.16 & 0.59 & 0.88 & 2.07 \\
\hline 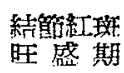 & 7.0 & 0.72 & 3.11 & 0.78 & 1.08 & 2.52 \\
\hline 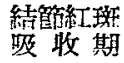 & 7.2 & 0.79 & 3.74 & 0.76 & 0.96 & 2.36 \\
\hline $\begin{array}{l}\text { 絬斯紅斑: } \\
\text { 涓退期 }\end{array}$ & 7.4 & 0.76 & 3.21 & 0.89 & 1.06 & 2.28 \\
\hline
\end{tabular}

第6表

癩性結節紅斑各期に於ける白血球百分此

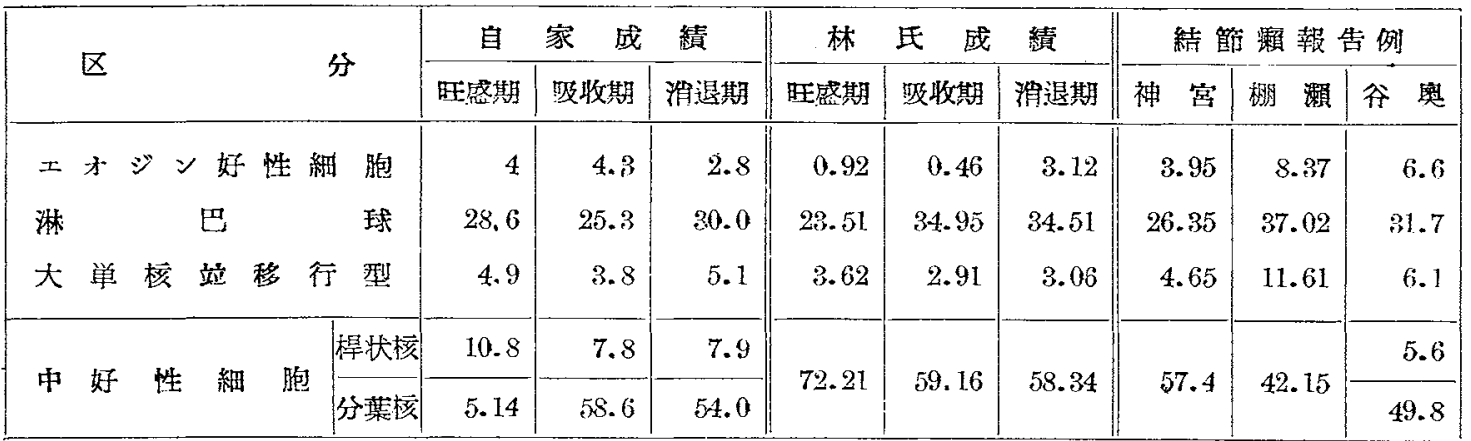

第 7 表

\begin{tabular}{|c|c|c|c|c|c|c|}
\hline \multirow{2}{*}{ 区 } & \multirow{2}{*}{$\begin{array}{l}\text { 蛋 } \\
\text { 㝵 }\end{array}$} & \multirow{2}{*}{$\mathrm{A} / \mathrm{G}$} & \multirow{2}{*}{ A } & \multicolumn{3}{|c|}{ グロブリン } \\
\hline & & & & $\alpha$ & $\beta$ & $\gamma$ \\
\hline 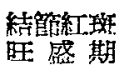 & 7.0 & 0.77 & 3.14 & 0.78 & 1.08 & 2.51 \\
\hline 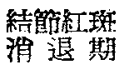 & $7 \cdot 4$ & 0.82 & 3.33 & 0.87 & 1.05 & 2.13 \\
\hline
\end{tabular}

